\section{The controversial experiments on the intravenous administration of drugs (and air!) during the cholera epidemic of 1867 in Italy}

\author{
MARCO CASCELLA
}

\section{ABSTRACT}

Cholera ravaged many American and European cities in the nineteenth century. Likewise, Italy was struck by six epidemics since the morbus first appeared in 1835-1837. After the International Sanitary Conferences held in Paris in 1851, there was a decrease of the cases due to consolidation of the city in terms of public and private health. Nevertheless, due to the lack of alternative and innovative remedies, the mortality remained unchanged, affecting more than 60 percent of patients. The city of Brescia in Northern Italy was severely hit by the epidemic of 1867. Not being able to implement effective therapeutic strategies, the administration of drugs like quinine and strychnine was proposed to be done intravenously. The results of intravenous injections were ominous, and all the patients died of 'sudden death'. Alhtough the academic authorities forbade further experiments, some physicians carried on a long trial using test animals and mental patients as 'guinea pigs'.

(Rev Med Chile 2015; 143: 1593-1597)

Key words: Administration, intravenous; Cholera morbus; Gastroenteritis; Mentally ill persons.

\section{Los controvertidos experimentos usando drogas y aire intravenoso durante la epidemia de cólera de 1867 en Italia}

El cólera arrasó muchas ciudades americanas y europeas durante el siglo XIX. Italia tuvo seis epidemias después de la primera aparición de la enfermedad en 1835-1837. Después de las Conferencias Sanitarias Internacionales de Paris en 1851, hubo una disminución de casos debido a una consolidación de la salud pública y privada. Sin embargo, debido a la falta de tratamientos innovadores, la mortalidad no cambió, afectando más del 60\% de los pacientes. La ciudad de Brescia en el norte de Italia fue afectada por la epidemia de 1867. Ya que no se pudieron implementar terapias efectivas, se propuso usar quinina y estricnina por vía intravenosa. Esto tuvo resultados ominosos ya que todos los pacientes tuvieron una muerte súbita. A pesar que las autoridades académicas prohibieron nuevos experimentos, algunos médicos hicieron un ensayo prolongado usando animales de experimentación y pacientes mentales. El fracaso de esta experiencia estimuló el desarrollo de la bioética.

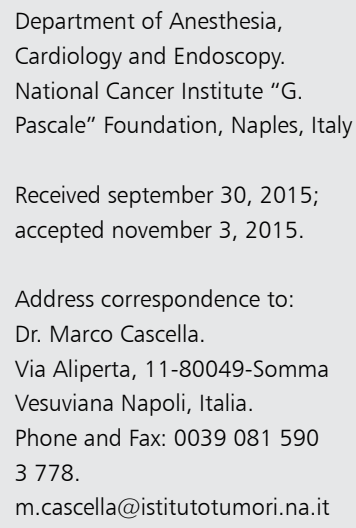




\section{Cholera and Cholera Morbus}

$\longrightarrow$ holera is an acute infectious disease of the small intestine which can lead to dehydration and even death if untreated. Although the classic symptom is large amounts of watery diarrhea, vomiting and muscle cramps may also occur. Diarrhea can be so severe that it leads within hours to severe dehydration and electrolyte imbalance. This may result in sunken eyes, cold skin, decreased skin elasticity, and wrinkling of the hands and feet. Nowadays cholera remains both epidemic and endemic in many areas of the world, occurring mainly in the developing world. It affects an estimated 3-5 million people worldwide, and causes 58,000-130,000 deaths per year ${ }^{1}$. Transmission is mostly from fecal contamination of food with Vibrio cholerae. This microorganism was first isolated in 1854 by the Italian anatomist Filippo Pacini (1812-1883) ${ }^{2}$ who also provided accurate therapeutic indications, recommending in extreme cases the intravenous injection of 10 g sodium chloride in a litre of water ${ }^{3}$. However, Pacini's finding was ignored and the discovery was attributed to the German microbiologist Robert Koch (1843-1910) who publicized it only 30 years later. Posthumous recognition came to Pacini 82 years after his death when the Judicial Commission of the International Committee on Bacteriological Nomenclature adopted 'Vibrio cholera. Pacini 1854 ' as the correct name of the cholera vibrio ${ }^{4}$.

The word "cholera" is an historical term used in the $19^{\text {th }}$ and early $20^{\text {th }}$ Centuries to describe both cholera and a number of other gastrointestinal diseases (sometimes epidemic) that resembled cholera $^{5}$. Nevertheless, before the discovery of the pathogen it was impossible to discriminate the various forms of gastroenteritis. Thus, in several treaties on this topic written in the $19^{\text {th }}$ Century the terms cholera and cholera morbus were used as synonyms ${ }^{6}$, and in this brief historical report these terms have been used interchangeably, even if it is not a correct methodology, as the purpose is the description of specific experiments rather than the analysis of the cause of the disease.

\section{Cholera epidemics}

Cholera ravaged many American and European cities in the $19^{\text {th }}$ Century, as a consequence of the colonization of India by the British Empire. Until then the disease had been confined in the India region between the Ganges and Brahmaputra rivers. Likewise, Italy was struck by six epidemics since the morbus first appeared in 1835-1837.

The International Sanitary Conferences, forerunners of the World Health Organization, were first convened in Paris in $1851^{7}$ to discuss the contagiousness of cholera. European scientists and public health officials attended the meetings, discussing the cause of the disease, the effectiveness of the quarantine and other strategies of public hygiene and therapy ${ }^{8}$. The debate between the proponents of contagionism (the theory that disease was spread from person to person) and anticontagionism was particularly heated. Nevertheless, because there were no alternative and innovative remedies, physicians continued to prescribe characteristic treatments like bleeding or opium, flowers of zinc, astringent, enemas, hot baths, and the use of alcoholic beverages, such as rum and mulled wine ${ }^{9}$. It is well known that homoeopathic remedies were also used, for example at the London Homoeopathic Hospital ${ }^{10}$.

As a consequence, despite the decrease of the cases due to consolidation of the city in terms of public and private health, the mortality remained unchanged, affecting more than 60 percent of the patients $^{11}$.

After the terrible epidemics of 1835-37 and 1854-55, and the more subtle and localized one of 1849 , a new cholera epidemic broke out in Italy in 1865 , lasting until 1867 . This latter was the fourth cholera pandemic, causing over 113,000 deaths (Figure 1) ${ }^{12}$.

\section{Experiments on Cholera Morbus in Italy}

In 1836 , the city of Brescia, in Northern Italy, was severely hit by this epidemic, as well as by the first cholera outbreak ${ }^{13}$. In the impossibility of implementing effective therapeutic strategies, the administration of drugs deemed as most effective -quinine and strychnine- was proposed to be done via the veins.

The experiments were made possible thanks to the recent introduction of metal needles and glass syringes, by Alexander Wood (1817-1884) and Charles Gabriel Pravaz (1791-1853).

Several remedies were tested, so the Italian 
physician Natale Zoja (1867-1912) tried the hypodermic and intravenous administration of alcohol.

"Doctor Zoia had injected 55 drops of a solution of alcohol and distilled water in the basilic vein in a 49 year old farmer... who died four hours later"14.

Another physician, Faustino Gamba (18391896), chief of the Brescian Choleric Lazaretto since 1867, administered strychnine intravenously in many of his patients. His experimental results, however, have never been revealed ${ }^{15}$.

The Brescian academic authorities proposed the experimentation with the combined intravenous administration of hydrochloric acid and hydrogen sulfide, which "preserve the nervous system and allow the expulsion of the choleric bane"14.

During the 1867 epidemic, one of the major Brescian medical authorities was Rodolfo Ridol$\mathrm{f}^{16}$. He was born in 1827 in Bogliaco, a town in Northern Italy near the city of Brescia. His father Giulio, a member of an ancient and important family of doctors and soldiers, was also a highly regarded physician and surgeon at the Women's Hospital of Brescia, a very old and prestigious hospital. Indeed, the Ospedale della Pietà di Brescia (Piety Hospital of Bresca) was built in 1523 to accommodate patients suffering from infectious di-

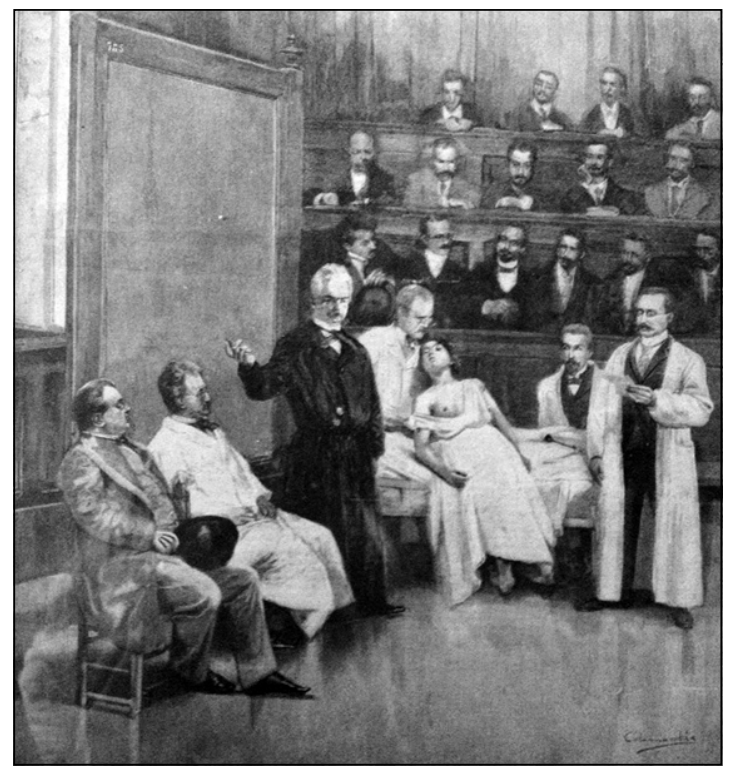

Figure 1. Lesson on infectious diseases. Italian woodblock-printed illustration. Second half of the $19^{\text {th }}$ century. Property of the author. seases. In the mid-nineteenth Century, the central body of this hospital was enlarged by annexing the adjacent convent of San Domenico, and then this structure was used as a "women's ward", changing its name to 'Women's Hospital'.

Rodolfi was living in a historical context of great importance for the nascent Italy. Thus, during his university years, he took part in the First Italian War of Independence from Austrian domination in 1848, and along with other university students he formed a battalion called 'The Crusaders of Padua', which operated mainly in defense of Venice from the Austrian siege.

Despite the war and the defeat of the insurgent Italian patriots, Rodolfi managed to graduate in medicine in September of the same year (University of Pavia) and began to serve in the Women's Hospital, following his father's footsteps. His work as a doctor was highly appreciated and, in 1854, he was appointed Chief Physician at the age of 27. When the Austrian government closed the University of Pavia (1849-50), he became Professor of Anatomy at the School of Medicine located at San Domenico Hospital ${ }^{17}$.

Rodolfi was a firm believer of the value of trying new routes of administration in both patients and vivisected animals, claiming they were "the only scientific methods capable of giving a new impulse to medical sciences" 14 .

Against the cholera epidemic, Rodolfi tried the method proposed by Beral in 1840 and popularized in Italy by the Neapolitan Domenico Guglielmi. This remedy involved the oral administration of ammonium citrate, in solution with ammonia ${ }^{18}$.

"During the administration of citrate of iron do not drink any beverage which would promote more abundant and unrestrained vomiting... in order to satisfy the insatiable thirst that torments the sufferer, it is possible to eat only scraps of snow... in severe cases add some dollops of good wine"14,19.

After an initial enthusiasm the Brescian physicians realized the futility of Beral's therapy, also taking in consideration statistical reports showing a high rate of mortality in other Italian regions where the same remedy was being administered ${ }^{20}$.

Thus, doctor Rodolfi and other physicians focused on the intravenous route of administration of drugs. However, the results of intravenous injections were ominous, and all the patients died of 'sudden death'. Therefore, the academic authorities declared that it was the doctor's duty 


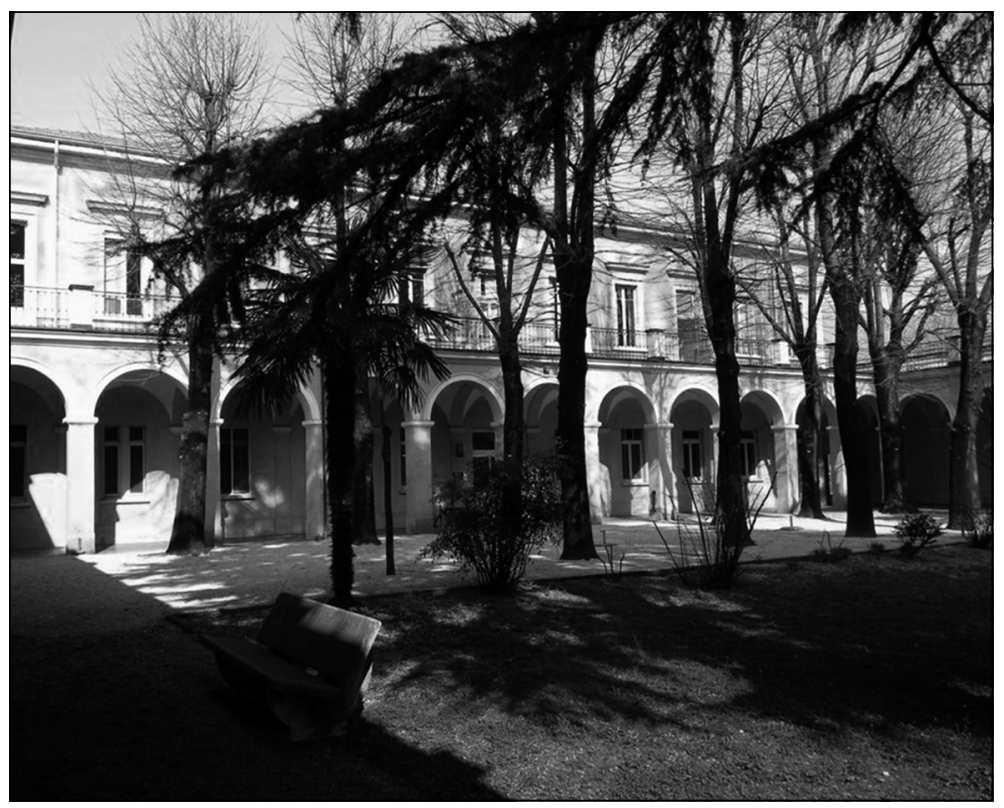

Figure 2. The Provincial Psychiatric Hospital of Brescia (1893-1978), Nothern Italy. to "abstain from the practice to stop the evil from increasing" 14 . Despite this prohibition the experiments on the intravenous administration did not cease and Rodolfi carried on a long "trial" using test animals in which he injected laudanum, strychnine, alcohol solutions or hydrogen peroxide, using a Pravaz syringe directly on their jugular veins. After the administration of substances the animals were sacrificed for pathologic findings.

During one of these experiments, Rodolfi injected some air into the jugular vein of a dog. To everyone's amazement, the dog did not die. Rodolfi tried to gradually increase the dose of air into the jugular vein, first administering two Pravaz syringes and then three. Also in this case, the dog resumed its viability after a first phase of stunning ${ }^{14}$. These observations convinced Rodolfi that air administration into the veins could be deadly only in very large quantities and especially if the administration coincided with a deep breath of the animal, which would have "pushed the big air bubble into the lungs". The experiments with the intravenous air were accompanied by a series of pathologic findings on the effects of asphyxia, and Rodolfi observed different organ damage, even in the brain parenchyma.

Unfortunately, these studies, lacking a proper controlled methodology and far from following the dictates of modern bioethics, were also conducted in humans. After a series of unsuccessful experiences in patients it was ordered that the experiments had to be performed only in asylums, using the hospitalized mental patients -then called 'brutes'- as 'guinea pigs' ${ }^{\prime 14}$.

\section{The criticism}

The criticisms leveled at the proponents of testing in the alienated were ferocious. Rodolfi's fiercest opponent was Giovanni Battista Navarrini. In a manuscript published in the Yearbook of the University of Brescia in 1874, he stated that the object of the research (i.e. cholera morbus), had an unidentified genesis and, therefore, it was inconceivable to perform tests on humans without a precise 'sense of direction'21. Summarizing, $\mathrm{Na}$ varrini clearly exposed the lack of faithfulness of Rodolfi's experiments to the strict criteria of the scientific method.

According to Navarrini it would have been more straightforward to produce an experimental model of cholera (in guinea pigs) on which to study the intravenous route of administration, using drugs with a precise dosage planning ${ }^{20}$. Unfortunately, we do not know if these experiments 
had actually been made since there are no traces about them in university documents.

In spite of the criticisms, Rodolfi kept performing his experiments in mental patients. Indeed, he published the results of one full year of research (from August 1874 to August 1875) on blood transfusion, performed in the Mental Hospital of Brescia (Figure 2) 22,23.

Rodolfi's work is an example of the experimental medicine of the $19^{\text {th }}$ Century, often far distant from basic rules of ethics and humanity. However, the strong criticism by many scientists of his time is a positive sign of the rise of a stronger social conscience.

\section{References}

1. Lozano R, Naghavi M, Foreman K, Lim S, Shibuya K, Aboyans V, et al. Global and regional mortality from 235 causes of death for 20 age groups in 1990 and 2010: a systematic analysis for the Global Burden of Disease Study 2010. Lancet 2012; 380 (9859): 2095-128.

2. Pacini F. Microscopic observations and pathological deductions on Asiatic cholera [in Italian]. Gazzetta Medica Italiana, Toscana, 2nd series 1854; 4 (50): 397-401 and 4 (51): 405-12.

3. Howard-Jones N. Robert Koch and the cholera vibrio: a centenary. BM J (Clin Res Ed) 1984; 288 (6414): 379-81.

4. Judicial Commission, International Committee on Bacteriological Nomenclature. Opinion. International Bulletin Bacteriological Nomenclature 1965; 15: 185.

5. Rosenberg CE. The Cholera Years the United States in 1832, 1849, and 1866. University of Chicago Press, Chicago. 2009. p. 74.

6. Boisseau FG. Traité du Choléra-Morbus, considéré sous le rapport médical et administratif, ou Recherches sur les symptômes, la nature et le traitement de cette maladie, et sur les moyens de l'éviter; suivi des instructions concernant la police sanitaire, publiées par ordre du gouvernement. Baillière, Paris. 1831.

7. Bynum WF. Policing hearts of darkness: aspects of the international sanitary conferences. Hist Philos Life Sci 1993; 15 (3): 421-34.

8. Tognotti E. The Asiatic Monster. History of Cholera in Italy [in Italian]. Editori Laterza, Bari. 2000.

9. Vicentini CB, Altieri L, Manfredini S. The treatment of cholera in Ferrara (Italy): the European epidemic scenery in the first half of the 19th century. Pharm Hist (London) 2011; 41 (3): 34-41.

10. Leary B. The homoepathic management of cholera in the nineteenty century with special reference to the epidemic in London, 1854. Med Ges Gesch 1997; 16: 125-44.

11. Tognotti E. Lessons from the History of Quarantine, from Plague to Influenza A. Emerg Infect Dis 2013; 19 (2): 254-9.

12. Dhiman B, Greenough WB. Cholera. Plenum Corporation, New York. 1992.

13. Vaglia A. Cholera epidemic in Brescia in 1836 [in Italian]. Infez Med 2013; 21 (3): 229-34.

14. Rodolfi R. Experiments on the intravenous administration of drugs in men and brutes (sic) [in Italian]. Commentari dell'Ateneo di Brescia per l'anno 1874. Apollonio, Brescia. 1874. p. 36.

15. Folcieri G. In memory of Gamba Faustino [in Italian]. Commentari dell'Ateneo di Brescia per l'anno 1896. Apollonio, Brescia. 1896. p. 141.

16. Vernia GL, Vernia L. The Ten days of Rodolfo Rodolfi, patriot and physiacian [in Italian]. Roncadelle 2009; 6: 16-17.

17. Folcieri GA. In memory of Rodolfo Rodolfi [in Italian]. Commentari dell'Ateneo di Brescia per l'anno 1896. Apollonio, Brescia. 1896. pp.116-8.

18. Guglielmi D. Method for curing the asiatic cholera with soluble iron citrate citrate-soluble iron [in Italian]. Salviucci, Roma. 1868.

19. Rodolfi R. On the Cholera morbus [in Italian]. Gazzetta Medica Italiana, Lombardia 1873; 37: 289-92.

20. From May 3 to June 29 giugno 1867, 490 deaths out of 690 patients were reported in Galatina di Puglia (Southern Italy). Gazzetta medica Lombarda, issue 31, August 5 1867, p. 285.

21. Navarini GB. On the value of the experiments on the brutes (sic) in therapy [in Italian]. Commentari dell'Ateneo di Brescia per l'anno 1874. Apollonio, Brescia. 1874. p. 49.

22. Norcio B. Care for mentally ill in Italy. BMJ 1993; 306 (6892): 1615-166.

23. Manzini GB, Rodolfi R. On blood transfusion: experiments performed by the doctors Giovanni Battista Manzini and Rodolfo Rodolfi in the mental hospital of Brescia [In Italian]. Rechiedei, Milano. 1876. 